\title{
INTERNATIONAL TRIPARTITE RUBBER COUNCIL: OBSTACLES OF THE AGREED EXPORT TONNAGE SCHEME POLICY, IMPLICATIONS ON THE EXPORTING COUNTRIES
}

\author{
Pazli Mahyuddin 1 《 iD, Rahmat Kurniawan ${ }^{2}$ iD \\ ${ }^{1}$ University of Riau Researcher on Regional Development Studies, University of Riau, 28293, \\ Pekanbaru, Indonesia \\ 2 Student International Relations at University of Riau, 28293, Pekanbaru, Indonesia
}

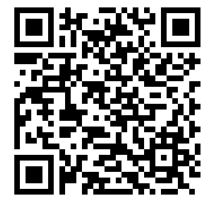

DOI: https://doi.org/10.29121/granthaalayah.v8.i8.2020.1193

Article Type: Research Article

Article Citation: Pazli Mahyuddin, and Rahmat Kurniawan. (2020). INTERNATIONAL TRIPARTITE RUBBER COUNCIL: OBSTACLES OF THE AGREED EXPORT TONNAGE SCHEME POLICY, IMPLICATIONS ON THE EXPORTING COUNTRIES. International Journal of Research GRANTHAALAYAH, 8(8), 336-345. https://doi.org/10.29121/granthaa layah.v8.i8.2020.1193

Received Date: 16 August 2020

Accepted Date: 31 August 2020

Keywords:

Rubber Council

Export Price

Economy Atmosphere

\section{ABSTRACT}

The export price of natural rubber, which fell sharply at the end of 2015, has prompted the International Tripartite Rubber Council (ITRC) to make an Agreed Export Tonnage Scheme (AETS) policy, which is to limit the volume of natural rubber exports from its members. Global rubber prices were bad at the end of 2015, causing the ITRC to implement AETS on a high quota scale in 2016. Did AETS in 2016 increase the price of natural rubber? if not why?. what are the implications for the exporting country? This study uses a descriptive method, which systematically describes a cause and effect event which is the topic of study.

It was found that AETS was unable to raise the price of global rubber exports, failing to create price stability. The implication is that the ITRC has agreed to reduce natural rubber exports with all the consequences. For this reason, even the best trade policy scheme design can fail, if the global economic and political atmosphere and the presence of new competitors are missed.

\section{INTRODUCTION}

This research discusses the policy of the International Tripartite Rubber Council (ITRC), namely the Agreed Export Tonnage Scheme (AETS), which is a limitation of the volume of natural rubber exports to the global market by countries that are members of the ITRC. In international trade, countries that have the same comparative advantage have become the custom to form organizations to strengthen themselves in achieving their goals. Likewise, the three countries as the largest natural rubber producers in the world did; Thailand, Malaysia and Indonesia agreed to form the ITRC. Like Clive, Archer where the international organization is a formal and ongoing structure formed by an agreement between members of both government and non-government from two or more sovereign countries with the aim of pursuing the common interests of its members (Clive, Archer. 2001).

Cooperation such as countries that are members of the ITRC, if it is associated with pluralist views, will not be limited to benefits such as Our-put and Out come, but has broader agendas such as socio-economic and welfare (Paul R Viotti and Mark V. 1998). Because after all pluralism states that both state actors and non-state actors who are

(C) 2020 The Author(s). This is an open access article distributed under the terms of the Creative Commons Attribution License, which permits unrestricted use, distribution, and reproduction in any medium, provided the original author and source are credited. 
included in political actors will depend on a forum and will compromise each other, and form a collaboration to achieve common goals.

For Indonesia, the plantation sector is one of the non-oil and gas sectors that has been able to provide the largest foreign exchange contribution in Indonesia. As Payaman (1983) states that plantations are a commodity other than oil and natural gas which has good potential and prospects in the world market, indeed for a long time the Indonesian plantation sector has been dominated by rubber and oil palm plantations. Likewise, Gideon stated that rubber is one of the plantation commodities that plays an important role as a source of foreign exchange because it is one of the non-oil and gas export commodities that makes a significant contribution (Gideon, 2017).

The percentage of the population that depends on agricultural commodities is quite large, therefore natural rubber plantations in rubber producing countries are the way of life for farmers. About $85 \%$ of rubber plantations in Indonesia are smallholder plantations, the rest are state-owned and private-owned plantations (BPS, 2017), therefore the rubber commodity is one of Indonesia's leading commodities.

In research that has been conducted by Happy Dewi Purnomowati, at. al where apart from being a source of income and community welfare as well as driving the economic growth of new centers around rubber plantations, natural rubber also contributes significantly as a source of foreign exchange for the country, considering that $84 \%$ of Indonesia's natural rubber production is exported in the form of raw rubber (Happy Dewi Purnomowati, at .al, 2015) In 2013, this sector contributed 4.61\% of Indonesia's total non-oil and gas exports which reached USD 149.9 billion. Indonesia is ranked 2 nd as a major global supplier of natural rubber, Indonesia's natural rubber exports grew by an average of 3.69\% annually from 2008 to 2013. In 2016, the Ministry of Industry of the Republic of Indonesia noted that Indonesian Rubber plantations were able to fulfill up to $6.24 \%$ of total foreign exchange income from the non-oil and gas sector. It can be said that the rubber plantation sub-sector has an important role in the source of Indonesia's development funds. This $6.24 \%$ contribution is supported by the productivity and area of rubber plantations which are recorded at 3,556 million ha, including the largest rubber plantation area in the world (BPS, 2015).

The world trade in natural rubber, which is marked by exports, has experienced a significant development since the automotive world experienced rapid development.

So that with the increasing production of these natural rubber producing countries, most of it is exported to several continents that require natural rubber, namely Asia, Africa, Australia, America and Europe. Most of Indonesia's natural rubber production is exported abroad and the rest is marketed domestically. In 2017, the top five importing countries for Indonesian natural rubber were the United States, Japan, China, India, and Korea (BPS, 2017)

Based on data from the World Integrated Trade Solution (WITS), 2015. Trade Statistics. UN-Comtrade, Geneve. From 2007 to 2015 Thailand was the main exporter with a 40\% share of the export market, while Indonesia was the second exporter of around 25\%. Apart from Thailand and Indonesia, another country which is the main exporter of rubber products is Malaysia with a share of around 10\%. and Vietnam with a share of around $7 \%$ during 2007 to 2015 (World Integrated Trade Solution, 2015).

Based on these data, it can be seen that rubber exports are very much dominated by ASEAN countries with a share of around 85\% during 2007 to 2015. Specifically, for data on Indonesia's natural rubber trade, in 2013 the export volume of Indonesian natural rubber reached 2.70 million tons, the value reached US \$ 6,906, 95 million. In 2014 , exports decreased by $2.9 \%$, namely to 2.62 million tons, where the value has reached US $\$ 4,741.49$ million, and then the 2015 data shows the volume of natural rubber exports has increased by $0.26 \%$ to 2,63 million tonnes where the value is US \$ 3699 million (BPS, 2015)

When viewed from the average production of natural rubber in Indonesia per year, compared to other natural rubber producing countries, it is still far behind or very low, because in 2013 Indonesia's natural rubber productivity was $1104 \mathrm{~kg} / \mathrm{ha}$, still inferior to China at $1160 \mathrm{~kg} /$ ha and The highest was India's average plantation productivity, which was $1800 \mathrm{~kg}$ / ha, then followed sequentially Thailand's productivity was $1790 \mathrm{~kg} /$ ha, Vietnam's productivity was $1720 \mathrm{~kg} /$ ha, Sri Lanka was $1550 \mathrm{~kg} /$ ha and Malaysia was $1500 \mathrm{~kg}$ / ha (Kementerian Perdagangan Republik Indonesia, 2014)

The selling price of natural rubber has fallen drastically since December 2010. ITRC member countries have restricted rubber exports to the global market. This restriction has succeeded in increasing the combined price of natural rubber from Indonesia, Malaysia and Thailand from USD 2.54 per to USD 2.9 per kg in early December 2012.

The next natural rubber export restriction was carried out again during October 2012 and March 2013. Unlike the previous impact, the implementation of the rubber quota limitation which was implemented in October 2012 
International Tripartite Rubber Council: Obstacles of The Agreed Export Tonnage Scheme Policy, Implications on The Exporting Countries

March 2013 had an impact positive and increased the price of natural rubber by USD 7.5 cent per pound or an increase of 5\%. The impact is that the price of natural rubber has reached a price of USD 149.85 cent per pound (Amri, A.B., 2012). After that it fell again by USD 134 cents per pound in February 2013 and continued to decline until it reached USD 59.51 cents per pound in September 2015.

According to Amri AB, (2012) the implementation of rubber export quotas during October 2012-March 2013 has increased the price of natural rubber by an average of US \$ 46 cent per pound compared to the average price during October 2000-September 2015. Furthermore, after implementing the production quota, The average price of natural rubber in Indonesia, Malaysia and Thailand fell by US \$ 3.3 cents per pound every month.

The state-owned plantation company, PT Perkebunan Nusantara IX, which is a state-owned company, also recorded a decline in the price of natural rubber until 2015, where the price of rubber fell to 1.99 percent for orders in 2015 (PT. Perkebunan Nusantara IX. 2015).

Phenomena and facts have shown that natural rubber in the ITRC countries continues to experience price declines in global trade. The reduction in prices has had profound implications for farmers in the production chain and reduced income for ITRC countries. Furthermore, countries that are members of the ITRC have taken steps to control prices by limiting the number of exports to the global market through the Agreed Export Tonnage Scheme, which is to limit the export quota of natural rubber from ITRC member countries to the global market in 2016.

Although the Agreed Export Tonnage Scheme has been implemented by ITRC member countries to increase the price of natural rubber commodities that are mired in the global market, this scheme has not been able to increase and maintain the stability of rubber prices permanently for quite a long time. There are always obstacles that challenge them in different ways in each AETS implementation.

Studies on the determinants of natural rubber exports have been carried out by several previous researchers using various approaches and results including: It has been researched by Siburian (2012) with the title of analysis of the factors affecting the export of Indonesian natural rubber to Singapore in 1980-2010. The analytical method used is the error correction model (ECM). The results have shown that in a short period of time Singapore's Gross Domestic Produc has a positive relationship with Indonesia's natural rubber exports to Singapore. In the long run GDP has a negative relationship.

The price of Indonesian natural rubber has a negative relationship to the export of Indonesian natural rubber to Singapore in both the short and long term. Meanwhile, Indonesian natural rubber production has a positive relationship with Indonesian natural rubber exports to Singapore both for a short time and for a long time.

It has been researched by Setyawati who analyzed the export demand for Indonesian natural rubber to the United States using secondary data for the years 1990-2011. Demand for Indonesian natural rubber exports to the United States fluctuates annually but the trend is increasing. Using the multiple regression method shows that the variables that have an influence on Indonesian natural rubber to the United States are the quantity of trade, the price of natural rubber, the price of natural rubber in the previous year, the price of synthetic rubber, and the exchange rate (Setyawati, et. Al. 2014).

Likewise, the research findings of Soleh Ahmad (2016) found the relationship between domestic rubber production and the volume of rubber exports in Indonesia was very high. Indonesia's rubber export volume has been influenced by domestic rubber production in the last four years.

Then Ambarwati, Rita (2019) found in her research that the response of Indonesian natural rubber exports is more responsive to changes in national natural rubber production compared to other variables in the short and long term. This means that any change in natural rubber production will be responded to by increasing and decreasing the amount of natural rubber exported.

Research conducted by Putri,Rizqi A and Pazli on the Implications of the United States Economic Crisis on Indonesian Rubber Exports, has found that the United States economic crisis has had a negative impact on Indonesian rubber exports, decreased export value, decreased prices and reduced rubber production in the world. Besides that, natural rubber exports carried out by rubber producing countries are strongly influenced by the ability of the buying countries such as the United States (Putri, Rizqi A, and Pazli Pazli, 2017).

Finally, the research conducted by Rahmawati, Nanda Nur (2018) used the results of multiple linear regression analysis with the ordinary least square (OLS) method regarding the effect of rubber production, international rubber prices and exchange rates on Indonesian rubber exports, it can be concluded that simultaneously the three variables namely rubber production, international rubber prices and the rupiah exchange rate have a significant effect on 
Indonesian rubber exports. 3. Partially, the three production variables, the international price of rubber and the rupiah exchange rate have a positive and significant effect on Indonesian rubber exports.

Previous studies that can be seen in their research findings include Siburian (2012); Setyawati, et. Al. (2014); Soleh, Ahmad, (2016); Ambarwati, Rita, (2019); Rizki and Pazli (2017); Rahmawati, Nanda Nur, (2018), who have found and seen the relationship between the variables tested and have shown the results. In summary they all found that natural rubber exports from Indonesia to the global market were accumulated influenced; Gross Domestic Product; trade quantity; natural rubber prices; natural rubber prices in the previous year; synthetic rubber prices; rubber production in the exporting country in the last four years; changes in natural rubber production; the financial capacity of the buying country as well as the international price of rubber and currency exchange rates.

So that previous researchers have the same research findings, but among them do not include very important variables, which natural rubber exports have been seen by previous researchers as a causal relationship only or a relationship between buying and selling goods in general.

It can be emphasized that the export of natural rubber from countries that are members of the ITRC or not from ITRC countries to the global market is one form of international trade. International trade is not simply seen as a relationship between the availability of money and the availability of goods. However, international trade in the form of exporting natural rubber to the global market is a stock investment. Stock investment absolutely requires fundamental analysis and technical analyst. Furthermore, exports which are part of trade will be determined or influenced by the psychological atmosphere of the market which is strongly influenced by the political-economic situation and the certainty of global security. This has been forgotten by previous studies where they did not include quantitative qualitative variables such as political and economic variables in importing countries or in global markets.

According to Porter (1990) a country gains a competitive advantage if its commodities are competitive. The competitiveness of a country is determined by the ability of the industry to innovate and increase the company's ability to gain competitiveness due to pressures and challenges. Exports are part of international trade.

Exports are possible due to several conditions, among others; There is a domestic surplus, so that the excess can be sold abroad through export policies; There is a foreign demand for a product even though the product is due to a shortage of domestic products; There is a greater profit from overseas sales than domestic sales, because prices on the world market are more profitable; There is bartering of certain products with other products that are designated and cannot be produced domestically; There is a political export policy (Sukirno, 2004).

So that the theory of international trade is defined as part of economics that studies and analyzes international economic transactions and problems including trade, finance and organizations, as well as economic cooperation between countries.

The agreement between Thailand, Malaysia and Indonesia in forming the International Tripartite Rubber Council organization is inseparable from the concepts of international organizations put forward by their experts. As the theory of International Organization put forward by Clive, Archers who underlie state or non-state actors to form trade or other organizations are because there is a common vision and interest in something (Clive, Archer, 2001). These interests temporarily bind trading partners by taking or not taking any action to achieve their common goals.

Likewise, Paul R Viotti and Mark V, (1998) who saw Thailand, Malaysia and Indonesia in the International Tripartite Rubber Council organization, are certain and are believed to have a broad agenda, namely prosperity. Of course, prosperity begins with how much wealth can be recorded as the views of those who adhere to a liberal perspective.

Adherents of a liberal perspective argue that the most effective way to increase the wealth of a country is to allow individuals in it to freely interact with individuals in other countries. They advocate free markets (Muhtar, Mas, oed, 2008).

Demand theory explains the nature of buyers' requests for something (Sukirno, 2012). Where demand is the amount demanded for a commodity at a certain price level and time period. Demand for a commodity is a comprehensive relationship between the quantity of a commodity that will be purchased by consumers during a certain period at a price level.

Domestic production is intended to meet the needs of the local people, but in conditions of overproduction it will encourage exports. A country's exports are the excess of domestic supply after deducting domestic demand or consumption plus the previous year's stock. 
As research that has been conducted by Siburian (2012); Setyawati, et. Al. (2014); Soleh, Ahmad, (2016); Ambarwati, Rita, (2019); Rizki and Pazli (2017); Rahmawati, Nanda Nur, (2018), where each of the previous researchers had found that natural rubber exports to the global market were influenced, among others; Gross Domestic Product; trade quantity; natural rubber prices; natural rubber prices in the previous year; synthetic rubber prices; rubber production in the exporting country in the last four years; changes in natural rubber production; the financial capacity of the buying country; international rubber prices and currency exchange rates.

In contrast to the problems and research results of previous researchers, where this research article is very important and exclusive compared to the problems and findings of previous studies, because this research article departs from research questions; why the Agreed Export Tonnage Scheme policy implemented by countries under the auspices of the International Tripartite Rubber Council, to increase the price of natural rubber they export to the global market, encountered obstacles that are beyond their calculations. Where the ITRC failed to increase and stabilize the global natural rubber price, even though the highest export quota restrictions had been implemented.

For this reason, the author is interested in submitting an article entitled: International Tripartite Rubber Council: Barriers to the Agreed Export Tonnage Scheme, Implications for Exporting Countries.

The important questions that want to find answers in this research are; Was the implementation of AETS in 2016 by ITRC (Thailand, Malaysia and Indonesia) successful in increasing and stabilizing the price of natural rubber? if not, why and what are the factors that caused the failure to create price increases and stability in the scheme implemented in 2016? Furthermore, what are the implications for the exporting country?.

\section{MATERIALS AND METHODS}

The author uses qualitative research methods, descriptive-analytical. Bogdan and Taylor in (Moleong, 2007) define qualitative research as a research procedure that produces descriptive data in the form of words both written and spoken and observable actors. Descriptive-analytical is an attempt to describe the results of the data obtained in the field, both orally and in writing to be analyzed as a research conclusion (Kartono, 1996).

The data collected in qualitative research is more in the form of words, pictures or objects, and not numbers. The groups or objects studied in qualitative research are usually small and not randomly assigned. Qualitative research is aimed at producing non-numeric data, namely data that is verbal in nature (Bakry, 2015). The data collection methods used in qualitative research vary. Information or data that has been collected through data collection methods is then analyzed interpretively, subjectively, impressionistically, or even diagnostically (Bakry, 2015).

\section{RESULTS}

\subsection{AGREED EXPORT TONNAGE SCHEME 2016 FAILED TO RAISE THE PERMANENT PRICE}

The author found that the 2016 AETS implemented by ITRC countries such as Thailand, Malaysia and Indonesia did not succeed in lifting down prices and stabilizing rubber prices. The planned export quota was not able to permanently increase the price of rubber. There are several factors that cause failure to create price increases and stability in the scheme implemented in 2016, including:

\subsubsection{EXCESS SUPPLY}

The excess supply is due to a number of new countries exporting natural rubber. Besides Vietanam, which has been exporting for a long time but is outside of ITRC members, it is added to the new natural rubber producing countries such as Myanmar, Laos and Cambodia.

For countries that were originally natural rubber exporters, such as Thailand, Indonesia, Vietnam, India, China and Malaysia, with a market share of 85.1 percent, especially with the entry of new natural rubber producing countries, it has resulted in excess supply in the global market. The AETS policy was unable to lift the downturn, stabilize rubber prices through export quota control. 
Pazli Mahyuddin, and Rahmat Kurniawan

\subsubsection{THE TRADE WAR (US VS PRC) HAD AN IMPACT ON THE WEAKENING OF THE YUAN CURRENCY}

The trade war between the United States and China began with Donald Trump's decision to raise import duties on steel by $25 \%$ on March 8,2016 . The policy received negative responses from many such as the European Union and China. On March 22, 2018, Donald Trump suspended the policy but did not apply to China. The United States continued to implement this policy against China, which China then retaliated by issuing policy to increase import duties on goods from the United States by 15-25\%. (Acinta Bunga Putri, 2019).

The trade war between China and the United States has intensified with the issuance of policies to increase import duties on goods from China such as cars, hard disks and aircraft parts. The trade war resulted in a weakening of the global economy which also affected global commodity prices due to the emergence of uncertainty in the Chinese economy.

As a result of the trade war, China experienced a 7\% decline in the value of the Yuan against the US Dollar. Demand for global rubber is still dominated by China, Western Europe, the United States, Southeast Asia and South Asia. The People's Republic of China is the largest natural rubber consuming country in the world, reaching an average consumption range of $40.5 \%$ of global consumption (Afrian Rudi, 2019).

\subsubsection{GLOBAL POLITICAL ECONOMY}

Market consolidation as evident from the tug of war between providers of goods and money providers, especially in the foreign exchange market, greatly affects foreign exchange rates. The Foreign Exchange Market, namely the price of a commodity, is related to the exchange rate of regional currencies against the United States dollar. If the strengthening of the US dollar exchange rate drops the exchange rate of other currencies, it will affect world rubber prices.

\subsubsection{NATURAL RUBBER EXPORTS FROM NON-ITRC COUNTRIES TO CHINA}

Natural rubber production in a year from ITRC countries is quite high. Countries that are members of the ITRC organization have become the largest natural rubber producers in the world. Their production is able to meet the world's demand for natural rubber up to 70\%. In 2016, for example, Thailand was able to produce up to 4.4 million tons, Indonesia produced up to 3.15 million tons, and Malaysia produced natural rubber up to 637 thousand tons. However, Vietnam, which is not a member of the ITRC, has shifted the position of Malaysia as the third largest producer in the world, where Vietnam is able to produce natural rubber up to 1 million tons per year. With a production of 1 million tons, Vietnam is here to enliven the global rubber market competition as well as become a competitor not only to become rivals of ITRC countries but also to other countries. Vietnam has exported natural rubber to the PRC, and has convincingly disrupted the global rubber market price amidst Vietnam's unavailability to join the ITRC. Besides, Laos also exports to China via Vietnam.

\subsection{IMPLICATIONS OF AETS FAILURE FOR EXPORTING COUNTRIES}

Most of the main export commodities based on natural resources are very vulnerable to price fluctuations because Indonesia's export commodities are not diversified into downstream production in the country. Usually, export performance will have an impact on the raw material supplier sector for the export industry in the exporting country.

The three main natural rubber producing countries, Thailand, Indonesia and Malaysia that are members of the International Tripartite Rubber Council have agreed to reduce their natural rubber exports. This effort was carried out through the continued AETS which aims to return world natural rubber prices to normal levels after falling in the previous year (CNBC, 2019).

However, the efforts of various countries to suppress exports have caused the domestic market price of rubber to be cheap, especially at the farm level. This is because the production continues but the excess goods are not exported. The length of time spent by farmers to feel the price of their livelihood commodities is cheap, causing a decrease in purchasing power of the community. Increase poverty and will contribute to inflation in natural rubber producing regions. 
International Tripartite Rubber Council: Obstacles of The Agreed Export Tonnage Scheme Policy, Implications on The Exporting Countries

\section{DISCUSSIONS}

Although there have been restrictions on the export volume of each natural rubber producing country, the AETS policy is powerless in increasing the price of natural rubber produced by the ITRC countries. The 2016 Agreed Export Tonnage Scheme can be said to have failed to raise the Permanent price.

\subsection{EXCESS SUPPLY}

The implementation of the AETS scheme in 2016 is the largest export volume limitation where the ITRC has agreed to limit rubber exports to 615 thousand tons. The AETS scheme was implemented to overcome the decline in natural rubber prices which did not exceed the price of US \$ 2 per kilogram. The AETS work scheme was implemented from March 2016 to August 2016 amounting to 615,000 tons due to the decline in rubber prices to below US \$ 1 per kilogram (Kementerian Perdagangan. Siaran Pers. 2016)

Indonesia received a share of 238,740 tons and the implementation of the scheme was considered successful due to the price increase that occurred in April 2016, but this increase was not able to be sustained, as indicated by the decline in rubber prices in 2017. Quoted from the databoks, price decreases have occurred throughout 2017 amounting to 33\% compared to 2016 (Databoks, 2018).

However, the efforts to suppress the production of the ITRC countries, on the other hand, also appear new competitors in the production of natural rubber which export so that the world natural rubber supply increases, this is what also affects the price of natural rubber from the ITRC. It is feared that the emergence of Laos, Cambodia, and Myanmar will be able to shift Indonesia and other ITRC countries as natural rubber exporting countries to China. This is because Laos exports to China via Vietnam due to cheaper logistics costs.

The decline in natural rubber prices has even reached the price of 1.3 US \$ per kilogram. On 22 December 2017, the ITRC agreed to limit rubber exports which took effect from January to March 2018. In January the increase occurred by $5 \%$, but was unable to be sustained. Based on the benchmark rubber price of the Tokyo Commodity Exchange, the price of rubber has decreased by $25.16 \%$ (Raditya Hanung, 2018).

\subsection{TRADE WAR (US VS PRC) AND THE WEAKENING OF THE YUAN CURRENCY}

China is a country capable of consuming up to 5 million tonnes of natural rubber per year. If China reduces the level of rubber consumption, the price of natural rubber will experience a sharp decline. The sharp decline actually affected the natural rubber producing countries the most in 2018 which was caused by the increasing balance of the Trade War between the PRC and the United States.

As the largest natural rubber consumer in the world, the decline in the level of Chinese rubber consumption has led to a decline in the price of natural rubber from ITRC member countries. The factor causing the decline in China's natural rubber consumption was influenced by the decline in car sales in China. The China Automobile Manufacturers Association (CAAM) said that sales fell 11.6 percent to 2.39 million units in September 2018 (Gabungan Industri Kendaraan Bermotor Indonesia. 2019).

\subsection{POLITICAL ECONOMY AND MARKET CERTAINTY}

The price of rubber in the international futures market, namely the price of rubber formed in Singapore (SICOM), is the reference for transactions by natural rubber business players. Apart from the SICOM stock exchange, the Tokyo Stock Exchange (TOCOM), and the Shanghai Future Exchange also play a role in the formation of world natural rubber prices. This is where the market physiology factor due to the trade war between the US and the PRC has also contributed negatively to the ITRC's efforts to make or break AETS. 


\subsection{NATURAL RUBBER EXPORTS FROM NON-ITRC COUNTRIES TO CHINA}

Vietnam's presence in the global rubber market is quite troublesome for other producing countries, because Vietnam does not join the ITRC, Vietnam is the largest natural rubber producer in the world with an average production of 1 million tons, and is one of the largest rubber exporting countries to Indonesia. China.

Since 2012, the ITRC has been trying to ask Vietnam to join the ITRC, but until 2018 Vietnam has not been willing to join. If Vietnam joins the ITRC, the ITRC will be able to control up to $90 \%$ of the world's total natural rubber production, and be able to control natural rubber prices and supplies in the world.

During the last 10 years, Vietnam's natural rubber production has increased. This increase shifted Malaysia as the third largest natural rubber producing country in the world, although in 2018, there was a decrease in the export volume of Vietnam's natural rubber by 17.9\% compared to 2017 (Virac. 2019). The condition in which Vietnam does not want to join the ITRC is one of the factors causing the difficulty of the ITRC to control the large supply of natural rubber in the global market through AETS.

As the liberal perspective argues that the most effective way to increase the wealth of a country is to let individuals in it freely interact with other countries. Liberals advocate free markets (Muhtar, Mas, oed, 2008). It is not an exaggeration, such as the actions of the Vietnamese state by exporting natural rubber to the PRC, where Vietnam did not want to join the ITRC as a very liberal act in trade.

\subsection{IMPLICATIONS OF AETS FAILURE FOR EXPORTING COUNTRIES}

The failure of AETS has significant implications for disrupting the export market which has minimized foreign exchange earnings, natural rubber production is not fast in the domestic industry, where the consumption of natural rubber in the ITRC countries is still low. The failure of AETS to raise the price of natural rubber also has implications for a number of new policies that must be taken immediately by exporting countries, namely their consistency in agreeing to reduce the export quota of natural rubber that has been set together. The dilemma is that reducing the export quota means leaving domestic rubber unable to be absorbed by the downstream industry in ITRC countries and the price becomes very cheap, especially at the lowest level of farmers, as a result it causes the purchasing power of rubber farmers to decrease, and will even increase the population poverty rate.

\section{CONCLUSIONS}

The failure of AETS to lift down prices and stabilize rubber prices was caused by the increasing supply of natural rubber in the global market originating from new producing countries such as Myanmar, Laos and Cambodia.

The trade war between China and the United States resulted in a weakening of the global economy, creating uncertainty over the Chinese economy, where the value of the Yuan against the US Dollar decreased by 7\%.

The Global Political Economy situation has resulted in a long period of consolidation of shares in the foreign exchange market, so that regional currency exchange rates are increasingly depressed against the United States dollar, this condition makes it very difficult for investors to make investment decisions.

Vietnam, which is not a member of the ITRC, is able to produce 1 million tonnes of natural rubber per year and has enlivened the global rubber market and has become a competitor by exporting natural rubber to the PRC country. Vietnam is able to disrupt market prices, especially since Laos also exports to China via Vietnam.

\section{SOURCES OF FUNDING}

This research received no specific grant from any funding agency in the public, commercial, or not-for-profit sectors.

\section{CONFLICT OF INTEREST}

The author have declared that no competing interests exist. 
International Tripartite Rubber Council: Obstacles of The Agreed Export Tonnage Scheme Policy, Implications on The Exporting Countries

\section{ACKNOWLEDGMENT}

Thank you for the very high appreciation, the authors present to many parties who have volunteered to help provide data, in the form of numbers and information.

\section{REFERENCES}

[1] Clive, Archer. International Organization. New York: Routledge, Taylor and Francis Group; 2001.

[2] Paul R Viotti dan Mark V. International Relations Theory: Relaism, Pluralism, and Beyond. Boston: Allyn and Bacond; 1998.

[3] Payaman J. Simanjuntak. Masalah Tenaga Kerja di Subsektor Perkebunan. Dalam Buku Perkebunan Indonesia di Masa Depan. Jakarta: Yayasan Agro Ekonomika; 1983.

[4] Gideon, A. (2017). Kementan: Neraca Perdagangan Pertanian Surplus US\$ 10,98 Miliar. Retrieved from bisnis.liputan6.com:2017, Tersedia di: http://bisnis.liputan6.com/read/3104496/kementan-neracaperdaganganpertanian-surplus-us-1098-miliar (22 September 2018)

[5] BPS, Stastistik Karet Indonesia, Direktoral Jenderal Perkebunan Indonesia, Statistik Perkebunan Indonesia Tree Crop Estate Statistic of Indonesia 2013- 2015, 2017, 14.

[6] Happy Dewi Purnomowati, Dwidjono Hadi Darwanto, Sri Widodo, Slamet Hartono, Jurusan Sosial Ekonomi Pertanian Fakultas Pertanian UGM, Vol.1, No.2, Juli 2015

[7] Badan Pusat Statistik Indonesia, Statistik Karet Indonesia, Direktoral Jenderal Perkebunan Indonesia, Statistik Perkebunan Indonesia Tree Crop Estate Statistic of Indonesia 2013- 2015, 2015, 5-19.

[8] BPS, Stastistik Karet Indonesia, Direktoral Jenderal Perkebunan Indonesia, Statistik Perkebunan Indonesia Tree Crop Estate Statistic of Indonesia 2013- 2015, 2017, 14.

[9] World Integrated Trade Solution (WITS), Trade Statistic.UN-Comtrade, Geneve, 2015 tersedia di wits.worldbank.org 1 Mei 2015, (24 Agustus 2020)

[10] Badan Pusat Statistik Indonesia, Statistik Karet Indonesia, Direktoral Jenderal Perkebunan Indonesia, Statistik Perkebunan Indonesia Tree Crop Estate Statistic of Indonesia 2013- 2015, 2015, 5-19.

[11] Kementerian Perdagangan Republik Indonesia, Analisis Komoditas Kopi dan Karet Indonesia: Evaluasi Kinerja Produksi, Ekspor, dan Manfaat Keikutsertaan dalam Asosiasi Komoditas Internasional. Pusat Kebijakan Perdagangan Luar Negeri Badan Pengkajian Dan Pengembangan Kebijakan Perdagangan Kementerian Perdagangan, 2014

[12] Amri, A.B. Desember. Harga karet naik usai ekspor dibatasi di 3 negara.Kontan. Tersedia di http://m.kontan.co.id/news/harga-karet-naikusaiekspor-dibatasi-di-3-negara; 2012 (November 2015).

[13] Amri, A.B. Desember. Harga karet naik usai ekspor dibatasi di 3 negara. Kontan. Tersedia di http://m.kontan.co.id/news/harga-karet-naikusaiekspor-dibatasi-di-3-negara; 2012 (November 2015)

[14] PT. Perkebunan Nusantara IX (PTPN IX). Harga karet 8 April: Jatuh Ke Bawah 200 Yen/Kg. Berita. Semarang. Tersedia di http://www.bumn.go.id (1 Mei 2015).

[15] Siburian, Onike, Analisis Faktor-Faktor Yang Mempengaruhi Ekspor Karet Alam Indonesia ke Singapura tahun 1980-2010. Universitas Negeri Semarang: Economics Develompent Analysis Journal.1, 2012

[16] Setyawati, Intan Kartika. Lin, Yoeng-Shenn. Setiawan, Budi. Analisis Permintaan Ekspor Karet Alam Indonesia Ke Amerika Serikat. AGRISE Vol. XIV, No. 2, Mei 2014.

[17] Soleh, Ahmad, Analisis Ekspor Dan Produksi Karet Di Indonesia (Aplikasi Model Lag Terdistribusi). EKOMBIS REVIEW: Jurnal Ilmiah Ekonomi dan Bisnis. 4, 2016.

[18] Ambarwati, Rita. Respon ekspor karet alam Indonesia. Master's Thesis. Fakultas Sains dan Teknologi Universitas Islam Negeri Syarif Hidayatullah Jakarta. 2019.

[19] Putri, Rizqi A, and Pazli Pazli. "Implikasi Krisis Ekonomi Amerika Serikat Terhadap Ekspor Karet Indonesia." Jurnal Online Mahasiswa Fakultas Ilmu Sosial dan Ilmu Politik Universitas Riau, vol. 4, no. 2, October 2017, 113.

[20] Rahmawati, Nanda Nur. Pengaruh Produksi Karet, Harga Internasional Karet dan Nilai Tukar Terhadap Ekspor Karet Indonesia. PhD Thesis. Universitas Muhammadiyah Surakarta. 2018.

[21] Porter ME.The Competitive Adventage of Nation. New York (US): The Free Press.1990.

[22] Sukirno, Pengantar Teori Mikroekonomi. PT Raja Grafindo Persada: Jakarta; 2004. 
[23] Clive, Archer. International Organization. New York: Routledge, Taylor and Francis Group; 2001.

[24] Paul R Viotti dan Mark V. International Relations Theory: Relaism, Pluralism, and Beyond. Boston: Allyn and Bacond; 1998.

[25] Paul R Viotti dan Mark V. International Relations Theory: Relaism, Pluralism, and Beyond. Boston: Allyn and Bacond; 1998.

[26] Muhtar mas.oed. Ekonomi-Politik Internasional dan Pembangunan, Yogyakarta; Pustaka Pelajar: 2008

[27] Sukirno, Sadono, Makro ekonomi Teori Pengantar. Jakarta: PT Raja Grafindo Persada; 2012.

[28] Moleong, Lexy J. Metodologi Penelitian kualitatif. Bandung; Rosdakarya: 2007.

[29] Kartono, Kartini. Pengantar Metodologi Riset Sosia. Bandung; Mandar Maju: 1996.

[30] Bakry Umar Suyadi. Ekonomi Politik Internasional: Suatu Pengantar. Yogyakarta, Pustaka Pelajar: 2015,106107

[31] Bakry, Umar Suyadi. Ekonomi Politik Internasional: Suatu Pengantar. Yogyakarta, Pustaka Pelajar: 2015,106107

[32] Acinta Bunga Putri, Uji Beda Ekspor Dan Impor Indonesia Sebelum Dan Sesudah Terjadi Perang Dagang Amerika Serikat Dan China, Jurnal Administrasi Bisnis (JAB). Vol. 71, No.1, Juni 2019

[33] Aprian Rudi, Harga Karet Tak Kunjung Naik, Ini Faktor-faktor Penyebabnya; Banyak faktor yang menyebabkan harga karet di pasaran internasional tak kunjung terkerek naik sejak 2013. Ed: M. Syahran W.Lubis tersedia di :https://ekonomi.bisnis.com/read/20191004/9/1155571/harga-karet-tak-kunjungnaik-ini-faktor-faktor-penyebabnya (24 Agustus 2020).

[34] CNBC Indonesia. RI Atur Kuota Ekspor Karet, Bagaimana Thailand \& Malaysia? Tersedia di: https://www.cnbcindonesia.com/market/20190401172123-17-64129/ri-atur-kuota-ekspor-karetbagaimana-thailand-malaysia), 2019 (28 Agustus 2020).

[35] Kementerian Perdagangan. Siaran Pers. Harga Karet Turun Tiga Negara Kurangi Ekspor 615 Ribu Ton. Tersedia di https://www.kemendag.go.id/files/pdf/2016/02/05/harga-karet-turun-tiga-negara-kurangiekspor-615-ribu-ton-id0-1454638427.pdf, 2018 (24 Agustus 2020).

[36] Databoks. Harga Karet Dunia Telah Turun 33\% ke 137 yen/kg. tersedia di: https://databoks.katadata.co.id/datapublish/2018/11/27/harga-karet-dunia-telah-turun-33-ke-137-yenkg 2018 (24 Agustus 2020).

[37] Raditya Hanung. Jokowi Resah Karena Harga Karet Memang Anjlok Parah. Berita Market. Tersedia di: https://www.cnbcindonesia.com/market/20181126125205-17-43696/jokowi-resah-karena-harga-karetmemang-anjlok-parah (24 Agustus 2020).

[38] Gabungan Industri Kendaraan Bermotor Indonesia. Pasar Otomotif di China Terendah dalam Tujuh Tahun Terakhir. Tersedia di: https://www.gaikindo.or.id/pasar-otomotif-di-china-terendah-dalam-tujuh-tahunterakhir/2019 (24 Agustus 2020).

[39] Badan Pusat Statistik Indonesia, Statistik Karet Indonesia, Direktoral Jenderal Perkebunan Indonesia, Statistik Perkebunan Indonesia Tree Crop Estate Statistic of Indonesia 2013- 2015, 2015, 5-19.

[40] BPS, Stastistik Karet Indonesia, Direktoral Jenderal Perkebunan Indonesia, Statistik Perkebunan Indonesia Tree Crop Estate Statistic of Indonesia 2013- 2015, 2017, 14.

[41] World Integrated Trade Solution (WITS), Trade Statistic.UN-Comtrade, Geneve Tersedia di wits.worldbank.org 1 Mei 2015 (24 Agustus 2020).

[42] Virac, Natural Rubber Industry. Tersedia di https://viracresearch.com/industry/vietnam-natural-rubbercomprehensive-report-q2-(2019)

[43] Muhtar mas.oed. Ekonomi-Politik Internasional dan Pembangunan, Yogyakarta; Pustaka Pelajar: 2008 